\title{
Test analysis for implementation of mechanical and robotic systems in therapy applications
}

\section{Análisis de pruebas para implementaciones de sistemas mecánicos y robóticos en aplicaciones de terapia}

AGUILERA-HERNÁNDEZ, Martha Isabel†*, ORTIZ-SIMÓN, José Luis, RAMÍREZ-AGUIRRE, Miguel and ROJO-VELÁZQUEZ, Gustavo Emilio

Tecnológico Nacional de México- Instituto Tecnológico de Nuevo Laredo, Mexico.

ID $1^{\text {st }}$ Author: Martha Isabel, Aguilera-Hernández / ORC ID: 0000-0001-8127-190X, Researcher ID Thomson: S-47242018, CVU CONACYT: 19115

ID $1^{\text {st }}$ Co-author: José Luis, Ortiz-Simón / Researcher ID Thomson: S-7037-2018, CVU CONACYT ID: 289883

ID $2{ }^{\text {nd }}$ Co-author: Miguel, Ramírez-Aguirre / ORC ID: 0000-0002-9780-0666

ID $3^{\text {rd }}$ Co-author: Gustavo Emilio, Rojo-Velázquez / ORC ID: 0000-0002-7792-1436, Researcher ID Thomson: S-47242018, CVU CONACYT ID: 26367

DOI: $10.35429 / J M E .2020 .13 .4 .10 .15$

Received January 15, 2020; Accepted June 30, 2020

\begin{abstract}
This article presents the results of tests performed on the mechanical system of wheeled robots, so they can be implemented as therapy instruments for people with different capacities (ASD). The results displayed show the robot's behavior following a trajectory and its dependence on operator handling. In this way, results can be extrapolated about the importance of design for the development of mechanical systems that can be reliable to be implemented as therapy tools.
\end{abstract}

Wheeled Robots, Therapy, Trajectory following

\begin{abstract}
Resumen
En este artículo, se presentan los resultados de las pruebas realizadas al sistema mecánico de robots con ruedas, con la finalidad de que puedan ser implementados como instrumentos de terapia para personas con capacidades diferentes (TEA). Se muestran los resultados en los cuales se analizó el comportamiento del robot para realizar una trayectoria y su dependencia del manejo del operador para realizarla. De esta manera, se pueden extrapolar resultados acerca de la importancia del diseño para la elaboración de sistemas mecánicos que puedan ser confiables para implementarse como herramientas de terapia.
\end{abstract}

Robots con ruedas, Terapia, Seguimiento de trayectoria

Citation: AGUILERA-HERNÁNDEZ, Martha Isabel, ORTIZ-SIMÓN, José Luis, RAMÍREZ-AGUIRRE, Miguel and ROJO-VELÁZQUEZ, Gustavo Emilio. Test analysis for implementation of mechanical and robotic systems in therapy applications. Journal of Mechanical Engineering. 2020. 4-13:10-15.

\footnotetext{
* Correspondence to the Author (Email: maguilera@ hotmail.com)

$\dagger$ Researcher contributing as first author.
} 


\section{Introduction}

Lately, robotics has taken a leading role in various applications due to its multidisciplinary nature. One of them is health. According to the World Health Organization, one in 160 children has autism spectrum disorder. This disorder is characterized by the presence of alteration of social behavior, communication and language at a certain level.

Studies have been carried out in which it has been identified that children with this disorder can coexist socially in a predictive environment (Pérez, 2019). This environment can be provided by the use of activities that involve robotic prototypes. Robots by their programming can have predictive behaviors and create an environment with these characteristics. Mechanical prototypes have been developed (Tejada, 2018), which consists of a pedaling system, which was focused on helping the autistic child to improve his concentration when performing tasks such as drawing, painting or writing. The child was pedaling at the time of the activity. The results have shown that this type of device helps to establish a better environment for the development of activities. This article is focused on the realization of robotic prototypes that are used in activities that create a predictive environment in which the autistic child's concentration can be encouraged to improve their skills. In development, the characteristics of the designed prototypes are presented. The results section shows the graphs showing the tests carried out on the prototypes so that they can be used as support in therapy. Finally, the conclusions of this work are presented.

\section{Development}

The prototypes consist of mobile robots with wheels controlled by a joystick via bluetooth. These have been programmed to follow a predefined trajectory. The user can select the autonomy option or manual control with joystick in the prototype. Three different types of prototypes were designed and tests were carried out to verify the repeatability in tracking the trajectory autonomously. The two options are placed since the robotic prototypes are to be used as a game tool to promote dexterity in autistic children and their level of concentration when controlling it manually. All prototypes have an ultrasonic sensor that detects obstacles, in this way the robot will not collide with the obstacle.
This is to promote a predictive environment that allows the user to interact with the environment without it being disturbed.

The tests were conducted on mobile robotic prototypes that differ in design, one has four wheels, with a motor on each wheel. The second has two controllable wheels and a castor wheel that serves to balance its movement. The third has rails for its movement. At this point, it is important to highlight that it is taken into account that the implementation of prototypes can be carried out at an economic cost. In this way, families or institutions do not have to make a burdensome or unattainable outlay to be able to incorporate play dynamics in autistic children. The main contribution of this work is to promote the use of robotic prototypes that are economically accessible, as well as the ease of implementation. The promotion of these has been sought as part of the mechatronic engineering program of our institution. Graduates of this institution will have the necessary experience to carry out the implementation of robotic prototypes that can be used mainly by health institutions dedicated to this type of specialized care in children with different levels of autism

The diagram of the first prototype is shown in figure 1, which consists of a mechanical structure with four wheels, with optical sensors for line tracking and ultrasonic sensors for the detection of an obstacle. The control system is carried out by means of the Arduino microcontroller and bluetooth communication is carried out by integrating the HC-05 module.

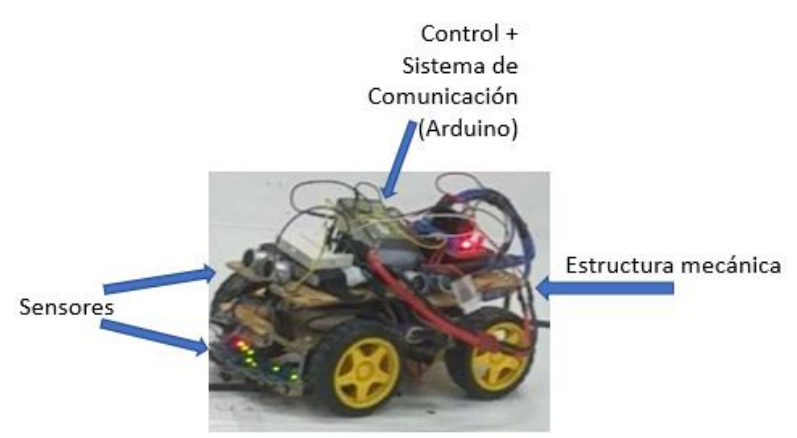

Figure 1 Description of Prototype 1
AGUILERA-HERNÁNDEZ, Martha Isabel, ORTIZ-SIMÓN, José Luis, RAMÍREZ-AGUIRRE, Miguel and ROJOVELÁZQUEZ, Gustavo Emilio. Test analysis for implementation of mechanical and robotic systems in therapy applications. Journal of Mechanical Engineering. 2020 
The prototype in Figure 1 is designed with four wheels and a motor on each wheel. It has a front differential control which allows the speed to be programmed on each wheel, leaving the steering to the front. The movement to the left or right with respect to the robot is obtained by the speed difference between the two front wheels. The route circuit, shown in Figure 3, consists of a black line in which trajectories were included in which the robot has to make 90degree turns and other more closed 45-degrees. The obstacles were implemented with plastic boats filled with sand, to give them stability and the robot does not knock them down, in case there is physical contact with them.

For manual control a video game joystick was added. This was done to be easy for the child to use. The joystick's enabled options were only four: forward, backward, turn left and turn right. Acrylic and wood are the materials used in the prototypes.

Acrylic provides a firm, smooth, resistant base and does not show deformation or sagging when the temperature changes. Wood, meanwhile, was used, since in the implementation of the prototypes it has been tried to include reusable materials, this in order to help the environment.

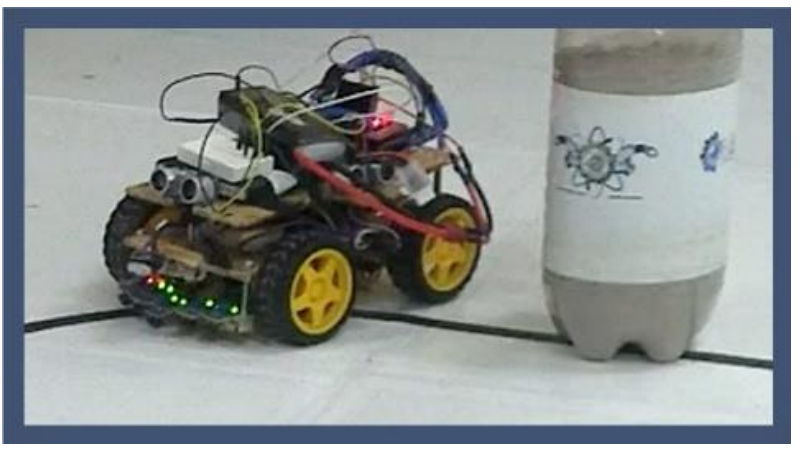

Figure 2 Prototype 1 dodging an obstacle

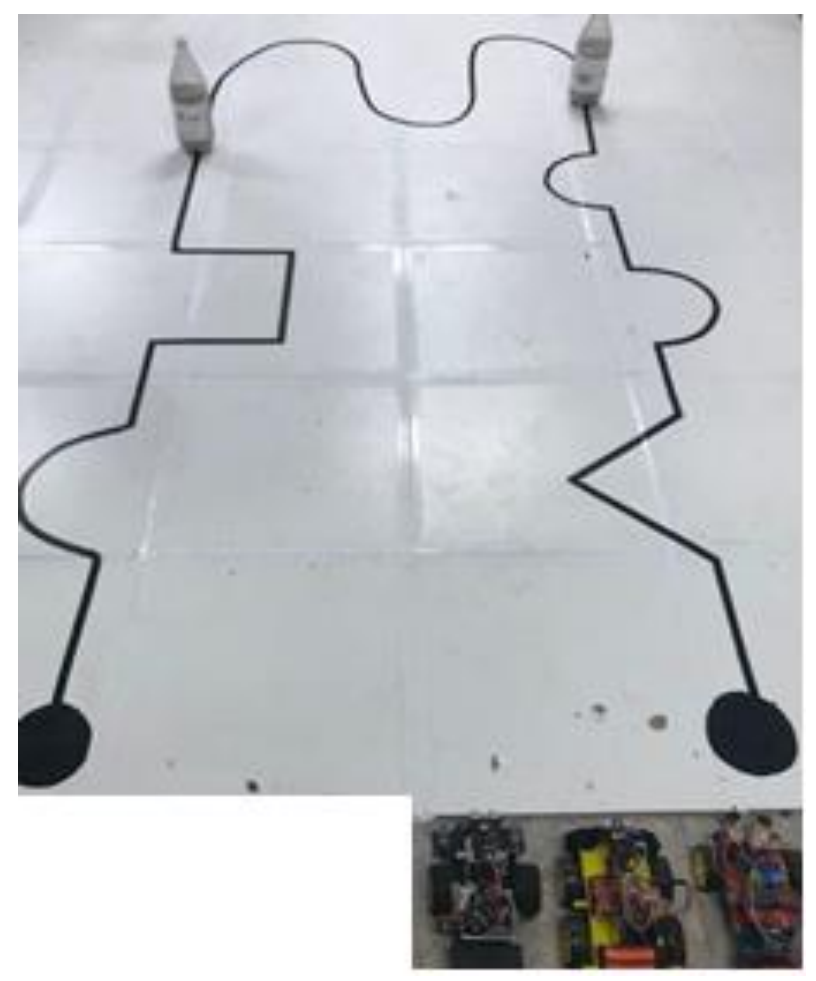

Figure 3 Test track example

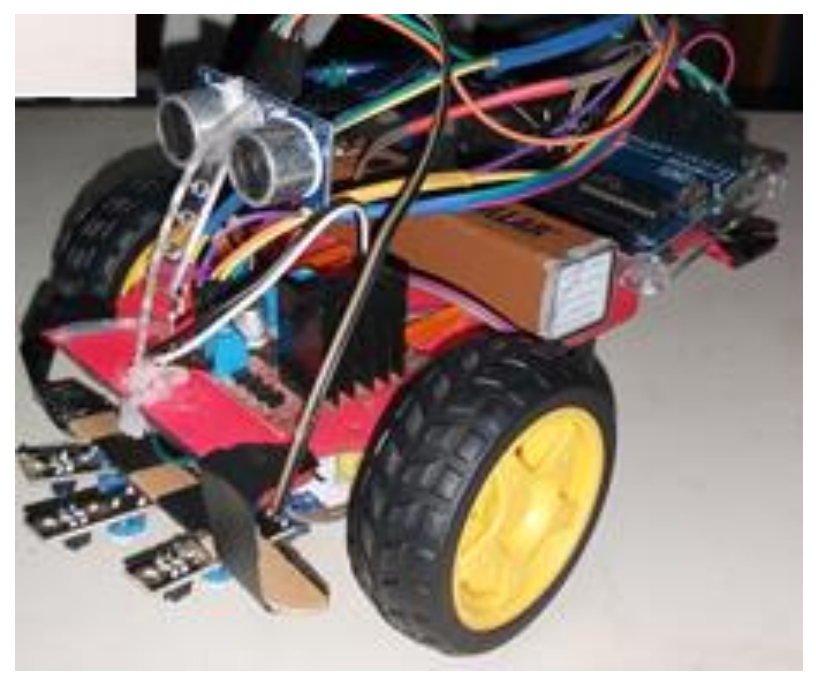

Figure 4 Prototype 2

Prototype 2, shown in Figure 4. It has two front wheels with differential control and a castor wheel at the rear for stability. Like Prototype 1, it has optical sensors for line tracking and an ultrasonic sensor for obstacle detection. Figure 5 shows the second prototype on its way autonomously.

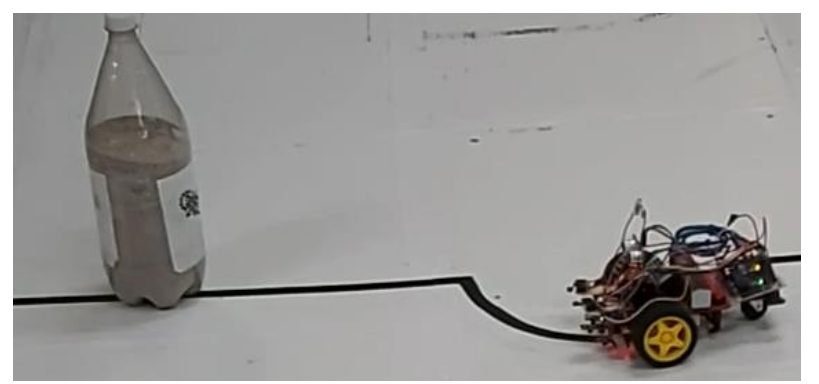

Figure 5 Prototype Tour 2

AGUILERA-HERNÁNDEZ, Martha Isabel, ORTIZ-SIMÓN, José Luis, RAMÍREZ-AGUIRRE, Miguel and ROJOVELÁZQUEZ, Gustavo Emilio. Test analysis for implementation of mechanical and robotic systems in therapy applications. Journal of Mechanical Engineering. 2020 


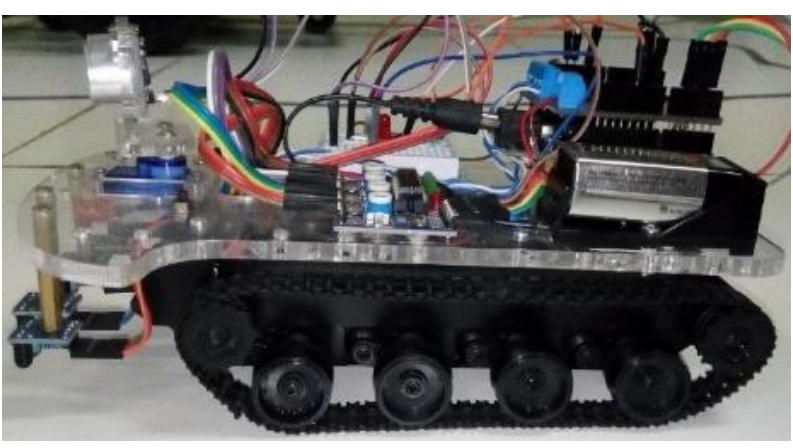

Figure 6 Prototype 3

Figure 6 shows the prototype that has rails as a mechanical part for its movement. It has two motors which allow differential control for the movement of the prototype.

The general concept of the project consists in the realization of prototypes, based on sustainable development, which contain a sensory system that allows them to carry out their journey on a trajectory. These prototypes will be used as support systems in therapy for the development of skills and adaptability in children with autism. Mechanical systems made by our institution in therapies have already been implemented (Tejada, 2018), these prototypes are considered an addition to these systems.

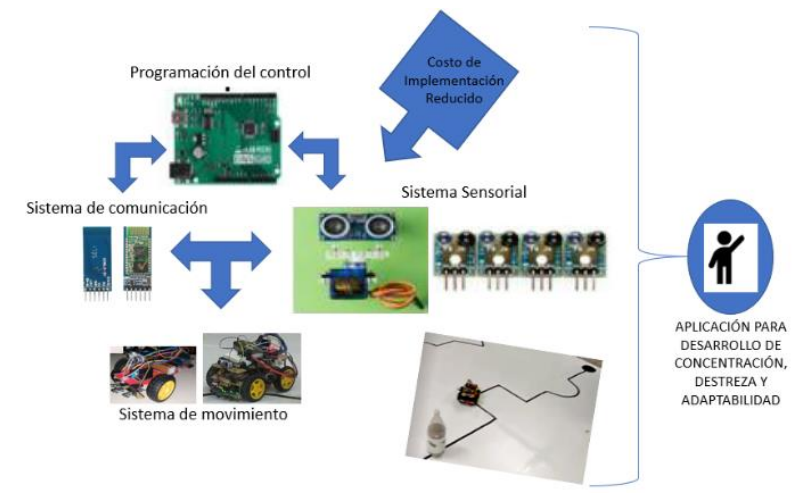

Figure 7 General Project Concept

\section{Results}

Table 1 shows the average time results autonomously. These data serve as the basis for obtaining the repeatability of the prototypes and assessing their potential for failure. In the activity, the prototypes are manipulated by the caregivers, the autistic child manipulates the remote control, which has the options of manual or autonomous. Graphs 8, 9 and 10 show the comparison of the data when the robot performs the trajectory for and against the hands of the clock.
These data check the repeatability of the trajectory following in the presence of obstacles.

\begin{tabular}{|r|r|r|} 
ROBOT & $\begin{array}{c}\text { Average travel } \\
\text { time clockwise } \\
\text { (seconds). }\end{array}$ & $\begin{array}{c}\text { Average travel } \\
\text { time } \\
\text { counterclockwise } \\
\text { (seconds). }\end{array}$ \\
\hline$\# 1$ & 50.9 & 51.7 \\
\hline$\# 2$ & 58 & 59.1 \\
\hline$\# 3$ & 61.3 & 62.6 \\
\hline
\end{tabular}

Table 1 Average time required by the prototype to finish the tour autonomously

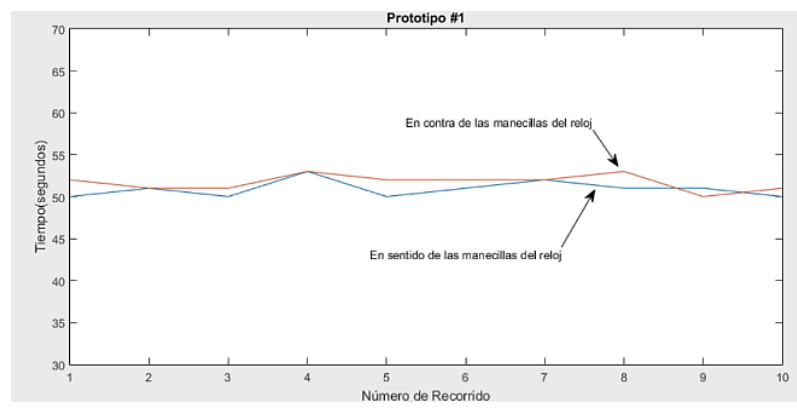

Figure 8 Prototype \# 1 walkthrough comparison

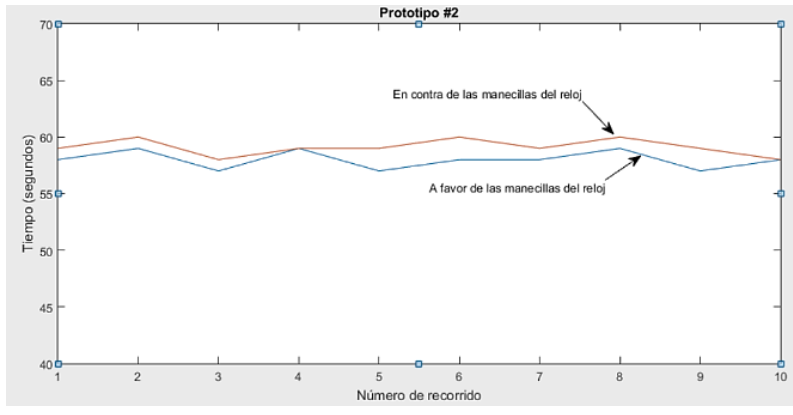

Figure 9 Prototype ride comparison \# 2

A test was carried out to verify that if the prototypes manage to attract the attention of the autistic child to establish a game dynamic. It must be recognized that the role of the caregiver (Vela, 2015) is an essential point for the activity to be carried out. He patiently explains to the child what the activity-game is about, and the results showed that it was possible to capture attention and even make several tours.

In the caregiver's experience, he indicated that afterwards the child was able to make a trace indicating the path followed by the robot. That is, the child did not trace the black path, but rather that of the robot. This point still requires study within the activities that can be carried out with these prototypes. In this test, time was not recorded, since the objective was to analyze whether the prototypes managed to attract the child's attention in a therapy session. 


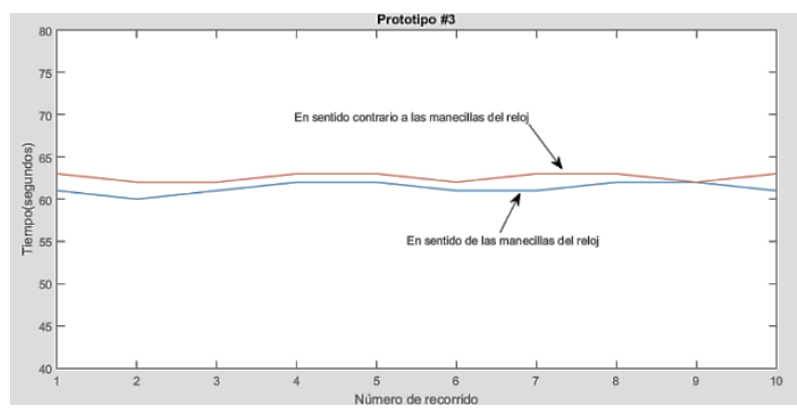

Figure 10 Prototype \# 3 walkthrough comparison

In addition, a repeatability study is presented with a larger robotic prototype \# 4 . The repeatability studies shown are presented in Figure 9.

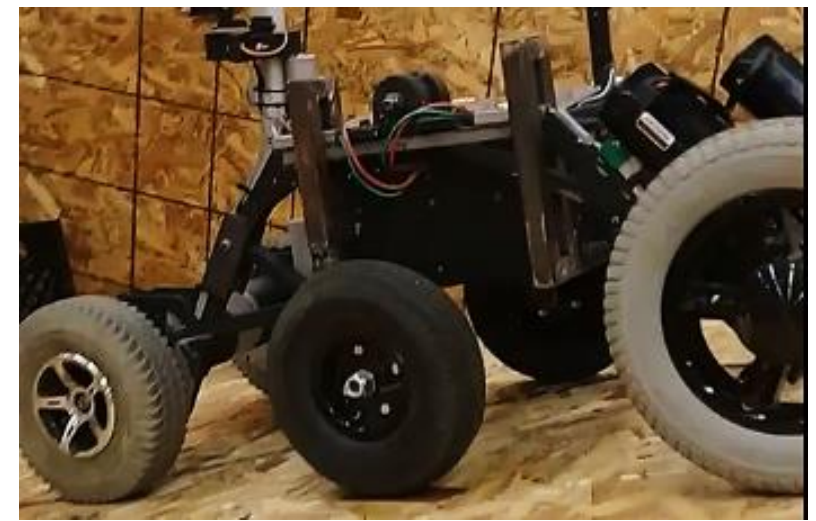

Figure 11 Robotic prototype \# 4

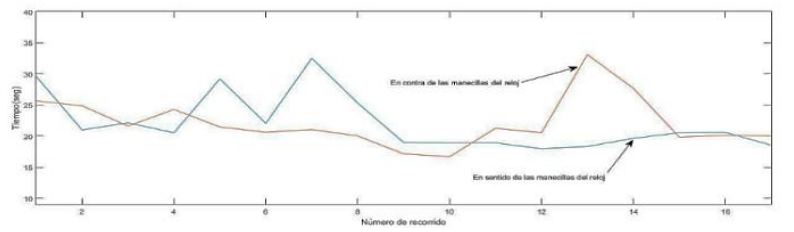

Figure 12 Prototype 4 repeatability study.

Although this prototype was not included in the test carried out with the infant, it is expected that it could be part of a set of prototypes that are available to people focused on giving therapy to autistic children, so that they can include them as part of their activities . The realization of covers for the prototypes is contemplated. These will be made with recycled material, plastic bottles will be used to cover the electronic part of the prototypes. Covers will be differently shaped to attract children's attention.

\section{Acknowledgments}

This work is part of the ITNLA-CA-2 project for Strengthening academic bodies of the National Technological Institute of Mexico.

\section{Conclusions}

Robotic prototypes were implemented with a sensory and communication system focused on being support in activities focused on the development of skills in autistic children. The prototypes have two modes, manual and autonomous. In this way, it is intended that the activities with these prototypes take place in a predictive environment. The prototypes were developed to be low-cost and based on sustainable development. In this way, they can be used by therapists in low-budget institutions. The role of the caregiver-therapist remains decisive so that the incorporation of the prototypes in the activities can be carried out successfully. It is planned to expand the study of the impact of the incorporation of a greater number of robotic prototypes in various activities focused on the therapy of children with autism.

\section{References}

Aguilera, Ortiz, \& Rojo (2017). Proyecto de Aplicación de Control Difuso para Apoyo Didáctico en Clases relacionadas a Mecatrónica. Revista de Docencia e Investigación educativa, 3(8),

8-21. http://www.ecorfan.org/spain/researchjournals/ Docencia_e_Investigacion_Educativa/vol3num 8/Revista_de_Docencia_e_Investigacion_Educ ativa_V3_N8_2.pdf

Bonilla, M. D., \& Chaskel, M. D. (2018). Trastorno del espectro autista. CCAP, 15(1), 1927. https://scp.com.co/wpcontent/uploads/2016/04/2.-Trastornoespectro.pdf

Building Robota, a Mini-Humanoid Robot for the Rehabilitation of Children With Autism 2007, Aude Billard, Ben Robins, Jacqueline Nadel, Kerstin Dautenhahn 10.1080/10400435.2007.10131864 Assistive Technology

Erazo Santander, O. A. (2016). Elementos para la comprensión del trastorno de espectro autista. Poiésis,31,51.

https://doi.org/10.21501/16920945.2076 
Perspectives on Mobile Robots as Tools for Child Development and Pediatric Rehabilitation 2007, François Michaud, Tamie Salter, Audrey Duquette, Jean-François Laplante 10.1080/10400435.2007.10131863 Assistive Technology

S.P. Gaskill and S.R.G. Went. Safety issues in modern applications of Robots, 1996, Reliability Engineering and System Safety, 53(3):301 - 307 10.1016/S0951-8320(96)00053-1

Tejada-Velásquez, y., Aguilera-Hernández, m., \& Ortiz-Simón, j. 1. (2018). Sistema de pedaleo dinámico para concentrar la atención de niños con trastorno de espectro autista. Revista de Investigación y Desarrollo, 4(11), 6-10. http://www.ecorfan.org/spain/rj_investigacion_ d_xi.php

Vela Baizabal, C., \& Granados Ramos, D. E. (2015). Interacción en niños con trastorno del espectro autista. Revista de Enfermería Neurológica, 14(1), 37-44. https://doi.org/10.37976/enfermeria.v14i1.203 Warren, J., Adams, J., \& Molle, H. (2011). Arduino Robotics (Technology in Action) (1st ed.). Apress. 